\title{
Versacryl versus Chrome-Cobalt Clasps in Implant- Supported Partial over-Dentures
}

\author{
Ashraf E. Eskander, Samira I. Ibrahim and Mushira A. Dahaba \\ Faculty of Oral and Dental Medicine, Cairo University, Egypt
}

Correspondence should be addressed to: Ashraf E. Eskander; ashrafmarian@hotmail.com

Received date: 11 November 2013; Accepted date: 4 February 2014; Published date: 27 June 2014

Academic Editor: Alan Graham Thomas Payne

Copyright (C) 2014. Ashraf E. Eskander, Samira I. Ibrahim and Mushira A. Dahaba . Distributed under Creative Commons CC-BY 3.

\begin{abstract}
This study was conducted to evaluate the effect of the type of clasp assembly used in toothimplant-supported partial over-dentures on the supporting structures of the abutment and the implant. Fourteen partially edentulous male patients, mandibular Kennedy class II, were selected with \#21 or \#28 as the last standing tooth. Each patient received a skeleton partial over-denture supported by a single root-form implant in the area of \#18 or \#31. Patients were divided into two equal groups; group I received an implant-supported partial over-denture with a metallic gingivally approaching retentive arm, while group II received the same denture design but with a thermoelastic resin (Versacryl) gingivally approaching retentive arm. Evaluation of the terminal abutment and the implant was carried out both clinically and radiographically at the time of insertion, six and twelve months later. There was no statistically significant difference $(\mathrm{P}>0.05)$ in the gingival index scores or bone height changes in both groups. However, after twelve months, patients of group II showed a statistically significantly lower mean amount of bone loss $(\mathrm{P} \leq 0.05)$ compared to those of group I. Similarly, no statistically significant difference $(\mathrm{P}>0.05)$ was observed between the mean bone density measurements in both groups after six months. However, after twelve months, patients of group II showed a statistically significant increase in the mean bone density measurements $(\mathrm{P} \leq 0.05)$ compared to those of group I. The use of thermoelastic clasps was better accepted by the patients. Both, the implants and the abutments reacted more favorably with the use of Versacryl clasps.
\end{abstract}

Keywords: esthetic clasps, cast clasps, thermoelastic.

\section{Introduction}

Management of partially edentulous patients can still be a prosthodontic challenge.
Replacing the missing teeth with conventional removable partial dentures (RPDs) is the traditional method for the

Cite this Article as: Ashraf E. Eskander, Samira I. Ibrahim and Mushira A. Dahaba (2014), "Versacryl versus Chrome-Cobalt Clasps in Implant-Supported Partial over-Dentures ", Journal of Research and Practice in Dentistry, Vol. 2014 (2014), Article ID 948300, DOI: 10.5171/2014.948300 
treatment of partial edentulism as reported by Chikunov et al (2008).

In determining a proper treatment solution, it is important for the clinician to consider the patient's aesthetic expectations, socioeconomic situation and the prognosis for the prosthesis and remaining dentition as mentioned by Budtz-Jørgensen et al (2000).

Jivraj and Chee (2006) indicated that the differences in anatomy and biomechanics make treatment of posterior quadrants with dental implants substantially different to that of anterior areas. Without implants, when posterior teeth were lost, treatment options included a long span fixed partial denture or a removable prosthesis, especially when no terminal abutment was available. When teeth are missing, implant-supported restorations can be considered the treatment of choice from the perspective of occlusal support and preservation of adjacent teeth.

Turkyilmaz (2009) found that the lack of adequate support (tooth/soft tissue) results in displacement of unilateral and bilateral distal extension removable partial dentures. Placement of implants is one option for managing this problem. Distal implants may help to prevent displacement of distal extension removable partial dentures, and may be especially suitable for patients who cannot afford implant-supported fixed dental prostheses.

Elsyad and Habib (2011) found that implantsupported partial overdentures appear to be associated with reduced posterior mandibular alveolar ridge resorption. Moreover, Ohkubo et al (2008) recommended the use of a limited number of implants for the support of a removable partial denture (RPD) as they change a Kennedy Class I or II situation to that of a Class III.

In a study by El Mekawy et al (2012), it was found that the implant-supported removable partial dentures (ISRPD) had significantly greater occlusal force and contact area than the conventional removable partial denture (CRPD). The center of occlusal force of the ISRPD tended to move more distally compared to the CRPD. All the patients preferred the ISRPD for comfort, chewing, retention and stability. Therefore, one implant per edentulous area and a simple attachment technique yielded a stable distal extension RPD.

De Freitas et al (2012) reported an increase in patient satisfaction, and high survival rates of implants associated with mandibular removable partial dentures with distal extensions. This treatment approach could represent a low-cost and beneficial rehabilitation for free-end mandibular ridges.

In addition, Kaufmann et al (2009) found that the placement of few implants allows for maintaining a compromised residual dentition for support of RPDs. The combination of root and implant support facilitates treatment planning and enhances designing the removable denture. It also proves to be a practical rescue method.

Minoretti et al (2009) indicated that extraoral implants may also be used successfully to provide support for distalextension removable partial dentures in severely resorbed posterior alveolar ridges. However, Sykes et al (2002) reported that patients often cite lack of retention and poor esthetics as reasons for not wearing their partial dentures. Traditional metal alloy clasps have been shown to exert forces on abutment teeth that exceed those capable of producing tooth movement. In addition, metal display on anterior teeth is often unacceptable. Furthermore, in a study by Behr et al (2012), a 5-year survival rate of all clasp-retained removable partial dentures showed that fractures most frequently occurred in clasps (16.1\%).

Kunwarjeet et al (2012) indicated that removable cast partial dentures are used as definitive removable prostheses when indicated, but location of clasps may affect 
esthetics. So, when patients are concerned about esthetics, flexible partial dentures which are esthetically superior to flipper and cast partial dentures may be considered. Kaplan (2012) found that the new design potential of the flexible partial denture and its clasp allow for a new treatment approach to the well-established problems of retention, stability and strength. Not only can esthetic clasps removable partial dentures reserve some advantages, that removable partial dentures have such as less preparation and low cost, but they also can bring a metal-free smile to the patients, which is a new effective and affordable treatment option for partial edentulism as reported by $\mathrm{Yu}$ and Huang (2012).

Valplast or Flexiplast are super polyamides which belong to the nylon family. Nylon is a resin derived from dicarboxylic acid, diamine, aminoacids and lactin that may be used when the patient is concerned with esthetics as recommended by Singh et al (2013). The main benefit of nylon partial removable dental prostheses (PRDP) is the absence of a metal framework, providing improved aesthetics. In addition, polyamide denture base resins are thought to offer some advantages for patients who are allergic to heat-polymerized poly-methyl methacrylate (PMMA) resin. Unfortunately, the lack of a traditional framework reduces the rigidity and support of occlusal rests as reported by Hamanaka et al (2011).

Sykes et al (2002) found that the technopolymer materials (thermoelastic resins) have superior flexibility, and exert less force than the metals. The technopolymer clasps were up to ten times as flexible as the metal clasps, and they returned to their pretest dimensions after being stretched. In addition, they exerted forces on the abutment teeth that fall within the range of those considered safe for use. This coupled with their pleasing esthetics makes them suitable for use on periodontally compromised teeth, those with deep undercuts and on anterior teeth. Therefore, thermoelastic resin clasps have been used for esthetic denture rehabilitation as recommended by Osada et al (2013). A question now arises: does the type of clasp assembly used on the terminal abutment in tooth-implant-supported partial overdentures have an effect on the supporting structures of the implant and the abutment?

This study was conducted to compare between the effects of thermoelastic (Versacryl) versus chrome-cobalt retentive clasp arms on the supporting structures of the implant, and the abutment in implantsupported partial over-dentures, both clinically and radiographically.

\section{Materials and Methods}

Fourteen partially edentulous male patients, ranging from 34 to 48 years were selected for this study, with an average age of 42 years. Only male patients were selected to avoid any hormonal effect on the bone changes. All patients had a Kennedy Class II mandibular arch, with \#21 or \#28 as the last standing tooth and an intact opposing arch. Patients were free from any systemic or debilitating disease that may affect the bone quality or the post-operative healing, and osseointegration of the dental implant. All patients had an adequate inter-arch space, good oral hygiene and were non-smokers. Patients with temporomandibular joint disorders, grinding or bruxing habits and deep bite were excluded. The patients were informed about the nature of this research and their verbal consents were obtained.

\section{Patients' Grouping}

All patients received a lower partial overdenture supported by a single root-form implant $^{1}(10 \mathrm{~mm}$ in length and $3.7 \mathrm{~mm}$ in diameter) placed in the area of \#18 or \#31. Patients were divided into two equal groups, each of seven patients. Grouping was done randomly by coin flipping method. Patients of group I received an implant-supported skeleton partial over-denture, with a metallic gingivally approaching retentive arm on the terminal abutment. Patients of group II 
received the same partial over-denture design as group I, with a thermoelastic resin (Versacryl) $^{2}$ gingivally approaching retentive arm on the terminal abutment.

\section{Implant placement}

In the first surgical phase, the implant was installed in its proposed site, the cover screw was secured to the implant and the mucoperiosteal flap was repositioned and sutured. At the time of second surgical phase (after three months), the implants were exposed, the cover screws were removed and replaced by a healing abutment of suitable length that was replaced ten days later by a ball abutment ${ }^{3}$ of a suitable height (Fig. 1).

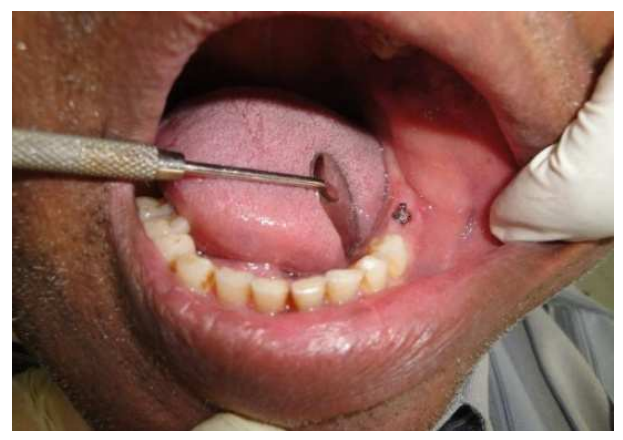

Figure1: Ball implant abutment secured to the implant.

\section{Removable partial \\ over-denture} framework construction

The partial over-denture design, which was the same in both groups (I and II),included a lingual bar as a mandibular major connector and a double Aker's clasp on the dentulous side. The difference between both groups was in the type of clasp adapted on the terminal abutment, which was a chrome- cobalt gingivally approaching retentive arm for group I (Fig. 2) and a Versacryl one for group II (Fig.3). A ball implant abutment with its metal housing and retentive cap was used on the implant side in both groups. Before denture delivery, the metal housing and retentive cap were attached to the fitting surface of the partial over-denture with autopolymerizing resin using direct pick-up technique.

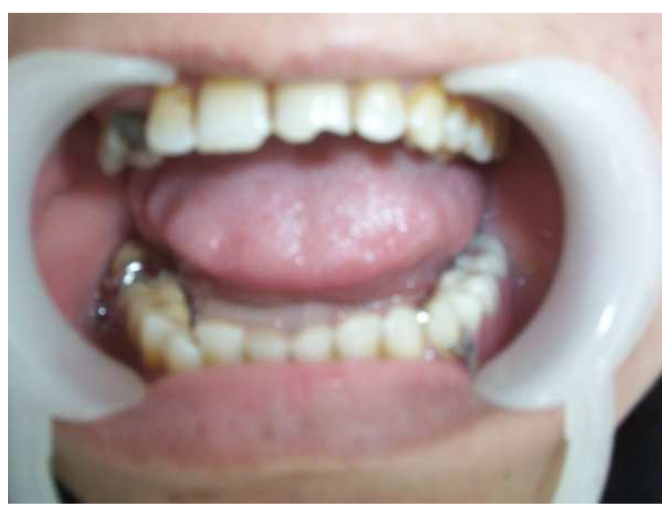

Figure 2: The finished partial over-denture with chrome-cobalt retentive arm (group I). 


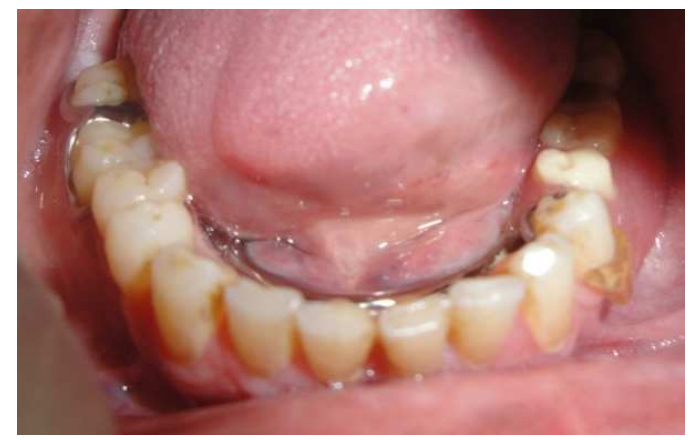

Figure 3: The finished partial over-denture with Versacryl retentive arm (group II).

\section{The evaluation of the terminal abutment and the implant:}

The evaluation of the supporting structures of the terminal abutment and the implant was carried out both clinically and radiographically at the time of prosthesis insertion, six and twelve months later

\section{a) Clinical evaluation}

\section{i) Patient satisfaction}

Patients' satisfaction with their prostheses was evaluated by means of a questionnaire developed in consideration of the most important aspects used to evaluate the prosthesis including esthetics, function, retention, stability and comfort. Patients were asked to rank each prosthesis from 1-3: not satisfied (1), satisfied (2), highly satisfied (3).

\section{ii) The Gingival Index Scores (GI)}

The Gingival Index Scores were recorded around the buccal, distal and lingual surfaces of the terminal abutment. The gingival tissues around the abutment were isolated and gently dried by a piece of gauze, and then each surface was individually scored according to the Gingival Index Scores (Loe and Silness, 1963). The mean of the three surfaces was calculated.

\section{iii) Evaluation of the implant stability}

The Evaluation of the implant stability was done using the Osstell device ${ }^{4}$ which measures the implant stability as an implant stability quotient (ISQ). Readings of 65 and above denote successful osseointegration, while readings below 65 denote failure osseointegration. The evaluation was carried out at the time of prosthesis insertion and twelve months later. The healing abutment was removed, and then the smart-peg' ${ }^{4}$ which coincides with the implant was screwed to it. The tip of the device was placed on each surface of the smart-peg, and the readings were recorded (Figs. 4,5) following the manufacturer's instructions.

Then, the smart-peg was removed and the ball abutment was secured again to the implant. After twelve months, the bone abutment was unscrewed, the smart peg was secured to the implant and the data of the ISQ were recorded. 


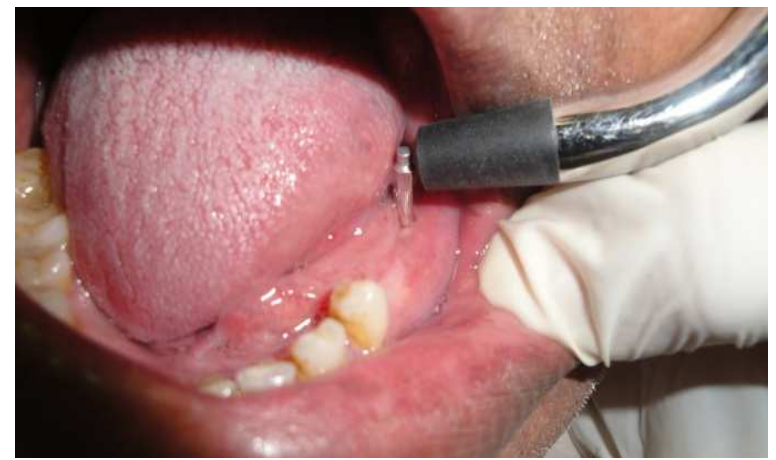

Figure 4: The tip of the Osstell device placed on the buccal surface of the smart peg.

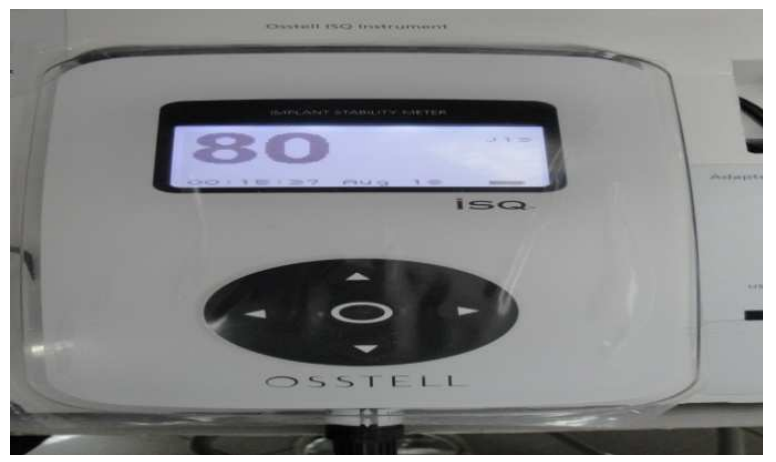

Figure 5: The readings of the Osstell

\section{b) Radiographic evaluation}

Marginal bone height measurements and densitometric measurements were carried out distal to the terminal abutment and mesial, and distal to the implant using direct digital radiography ${ }^{5}$.

Rinn-XCP ${ }^{6}$ periapical film holder, individually constructed radiographic templates, and long cone paralleling technique were used for the standardization of digital images (Fig. 6). A digital X-ray machine ${ }^{7}$ with a long cone, sixteen inches in length was used. The imaging plate was exposed by the X-ray machine at 70-kilovolt and 10-milliamperes, for 0.06 seconds. These procedures were carried out to standardize the acquisition of radiographic images in the different study periods for each abutment and implant. 


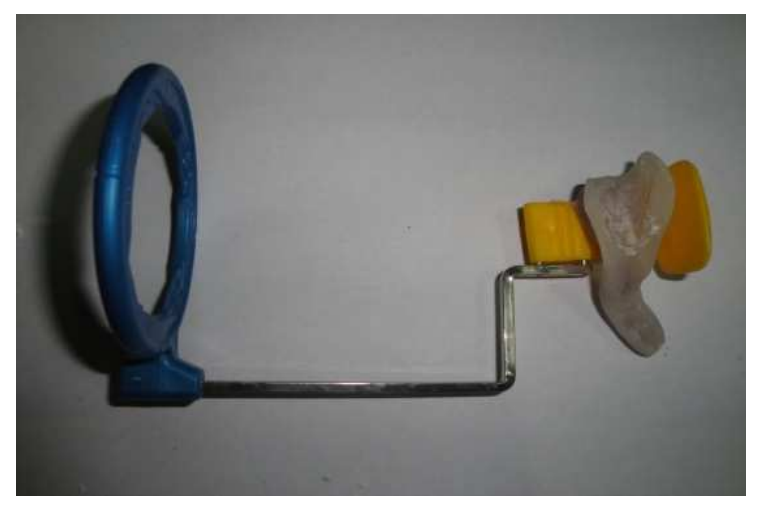

Figure 6: Aiming ring, Rinn-XCP film holder and radiographic template.

\section{i) Marginal bone height measurements}

The linear measurement system supplied by the special soft-ware of the Digora was used to assess the marginal bone height distal to the abutment and mesial, and distal to the implant along the follow-up periods. A line was drawn from the top of the abutment to its apex to calibrate the abutment length in the subsequent radiographs before measurements, and the same was done for the implant. This calibration ensured the standardization of all radiographic images along the follow-up period. After calibration, standardization of the measurements of the marginal bone height required that three lines were drawn, the first line passing tangential to the top of the implant, and two perpendicular lines passing parallel along the mesial and distal aspect of the implant (Fig.7). Another tangential line was drawn for the abutment, and a perpendicular line was drawn parallel along the distal aspect of the abutment. All perpendicular lines were drawn from a fixed point at the tangential line, and descending perpendicular toward the highest level of the alveolar bone. The distance recorded along these perpendicular lines was measured to record the alveolar bone changes; any increase in this distance denoted alveolar bone resorption.

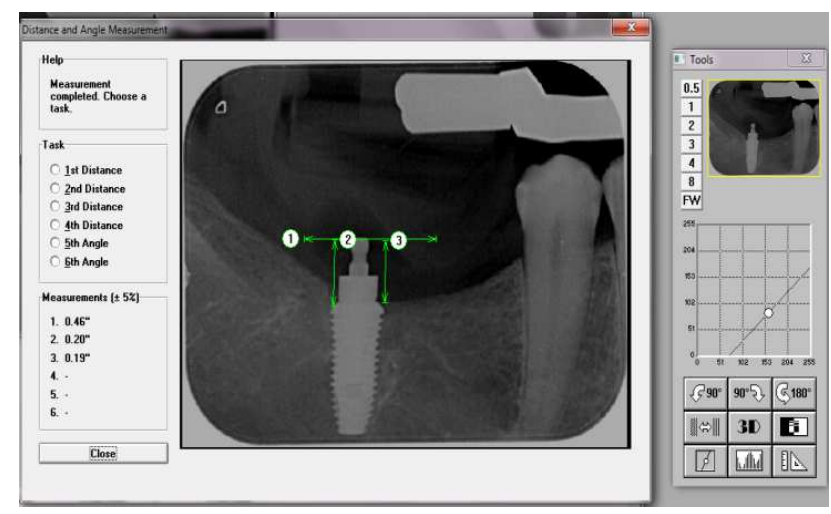

Figure7: Bone height measurements around the implant. 
ii) Bone density measurements (densitometric analysis)

Using the Digora software, three successive lines were drawn parallel and distal to the root of the terminal abutment. The first line extended from the cemento-enamel junction to the root apex, the second line was drawn parallel and equal to the first line and $1 \mathrm{~mm}$ apart from it, while the third line was drawn parallel and $1 \mathrm{~mm}$ apart from the second one. Then, the mean value of the three readings was calculated. For the implant, three successive lines (mesial and distal to each implant) were drawn extending from the first flute of the implant to its apex, and the mean value of the readings was calculated (Fig.8).

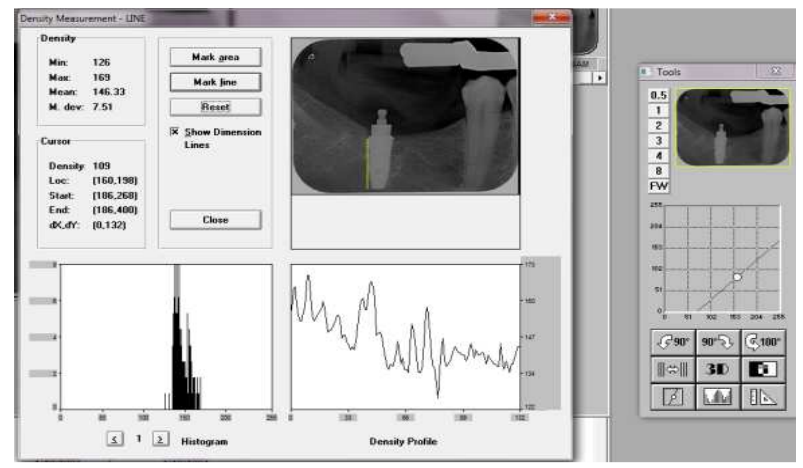

Figure 8: Bone density measurements around the implant.

\section{Results}

All patients in the two studied groups attended the whole follow-up period.

\section{I) Clinical evaluation}

\section{1) Patient satisfaction}

All patients in both groups were satisfied with their prostheses regarding stability and function. However, patients of group II were highly satisfied with the better esthetics and increased retention of the Versacryl clasps.

\section{2) The Mean Gingival Index Scores for the abutments in both groups}

The mean gingival index scores for the abutments in group I were $0.4,0.6$ and 1.0 at the time of prosthesis insertion, six and twelve months later respectively. However, for group II, the mean gingival index scores for the abutments were $0.5,0.6$ and 0.8 respectively. Comparison between the mean gingival index scores in both groups revealed no statistically significant difference $(\mathrm{P}>0.05)$ between both groups along the study period (Table 1, Fig.9). 
Table 1: Gingival Index scores for the abutments in both groups.

\begin{tabular}{|l|l|l|l|l|l|}
\hline & \multicolumn{2}{|c|}{ Group I } & \multicolumn{3}{c|}{ Group II } \\
\hline Period & Mean & S.D. & Mean & S.D. & P value \\
\hline Prosthesis insertion & 0.4 & 0.05 & 0.5 & 0.35 & \\
\hline 6 months & 0.6 & 0.15 & 0.6 & 0.20 & 0.160 \\
\hline 12 months & 1.0 & 0.25 & 0.8 & 0.05 & 0.48 \\
\hline
\end{tabular}

* Significant at $P \leq 0.05$.

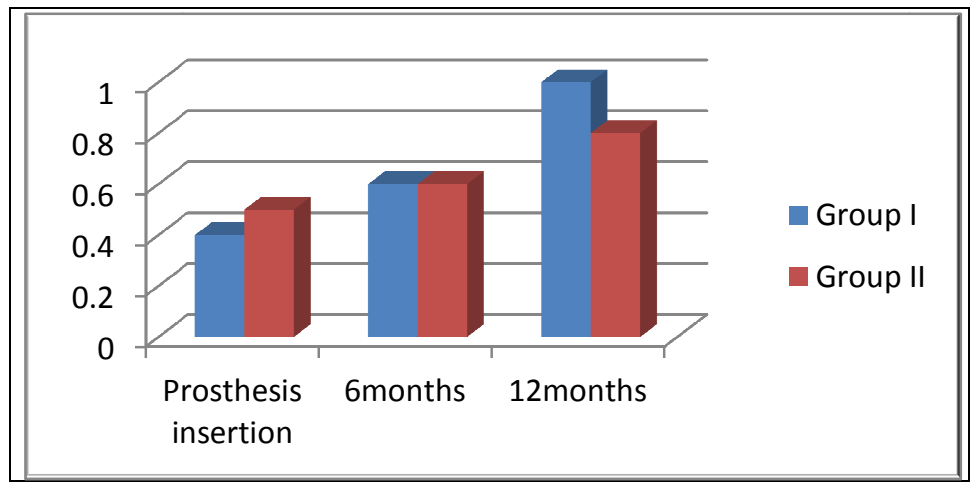

Figure 9: The Mean gingival index scores for the abutments in both groups.

\section{3) Evaluation of implant stability}

In each group, no statistically significant change $(\mathrm{P}>0.05)$ was observed in the mean difference in the values of the Osstell readings for the implants after twelve months of prosthesis insertion (Table 2, Fig. 10).

Table 2: The mean difference in the values of the Osstell readings for the implants in both groups.

\begin{tabular}{|l|l|l|l|}
\hline Group & $\begin{array}{l}\text { Mean } \\
\text { difference }\end{array}$ & SD & $P$-value \\
\hline Group I & 0.01 & 0.001 & 0.978 \\
\hline Group II & 0.000 & 0.000 & 1.000 \\
\hline
\end{tabular}




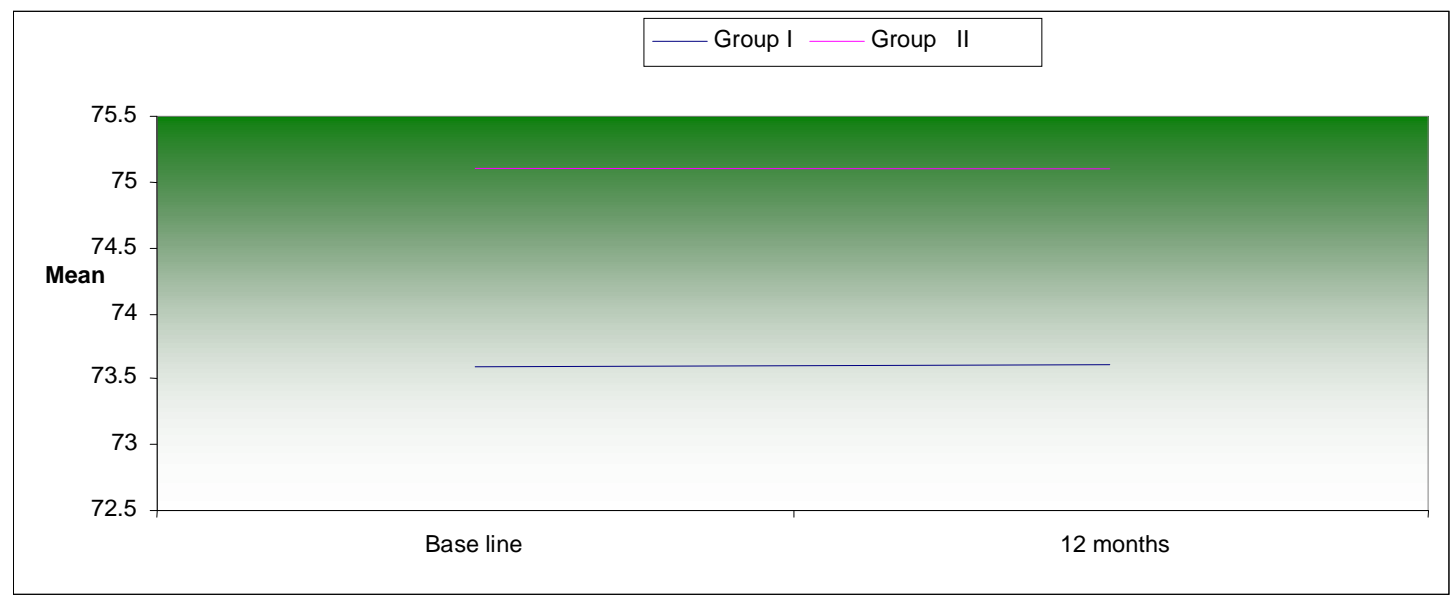

Figure 10: Line chart representing changes in the mean Osstell measurements.

\section{II) Radiographic evaluation}

\section{1) Marginal bone height measurements in both groups}

The mean marginal bone height measurements were recorded digitally. These vertical measurements represented the bone level distal to the terminal abutment and mesial, and distal to the implant, so that any increase in these measurements along the successive followup periods denoted bone resorption.

\section{a) For the abutments}

The mean marginal bone height measurements for group I were 3.24, 3.56 and $3.68 \mathrm{~mm}$ at the time of prosthesis insertion, six and twelve months later respectively. However, for group II, the mean marginal bone height measurements were $2.88,3.13$ and $3.18 \mathrm{~mm}$ respectively. The comparison between the amount of bone height changes in both groups revealed no statistically significant difference $(P>0.05)$ between the amount of bone loss in both groups after six months. However, after twelve months, patients of group II (the Versacryl clasp group) showed a statistically significantlower mean amount of bone loss $(\mathrm{P} \leq 0.05)$ than those of group I (the metal clasp group) (Table 3, Fig.11). 
Table 3: Marginal bone height measurements for the abutments in both groups

\begin{tabular}{|c|c|c|c|c|c|c|c|c|c|c|c|}
\hline & \multicolumn{2}{|c|}{ Group I } & \multicolumn{3}{|c|}{ Group II } & \multirow[t]{2}{*}{ Period } & \multicolumn{2}{|c|}{ Group I } & \multicolumn{3}{|c|}{ Group II } \\
\hline Period & Mean & S.D. & $\overline{\text { Mean }}$ & S.D. & $\begin{array}{l}\mathrm{P} \\
\text { value }\end{array}$ & & $\begin{array}{l}\text { Mea } \\
\mathrm{n} \\
\text { diff. }\end{array}$ & S.D. & $\begin{array}{l}\text { Mean } \\
\text { diff. }\end{array}$ & S.D. & $\begin{array}{l}\mathrm{P} \\
\text { value }\end{array}$ \\
\hline $\begin{array}{l}\text { Prosthesi } \\
\mathrm{s} \\
\text { insertion }\end{array}$ & 3.24 & 0.74 & 2.88 & 0.47 & & $\begin{array}{l}\text { Prosthesi } \\
\text { s } \\
\text { insertion } \\
-6 \\
\text { months }\end{array}$ & $\begin{array}{l}0.31 \\
8\end{array}$ & $\begin{array}{l}0.07 \\
6\end{array}$ & 0.296 & $\begin{array}{l}0.04 \\
1\end{array}$ & $\begin{array}{l}0.45 \\
7\end{array}$ \\
\hline 6 months & 3.56 & 0.52 & 3.13 & 0.35 & 0.141 & & & & & & \\
\hline $\begin{array}{l}12 \\
\text { months }\end{array}$ & 3.68 & 0.47 & 3.18 & 0.48 & $\begin{array}{l}0.042 \\
*\end{array}$ & $\begin{array}{l}6 \\
\text { months- } \\
12 \\
\text { months }\end{array}$ & $\begin{array}{l}0.44 \\
5\end{array}$ & $\begin{array}{l}0.08 \\
1\end{array}$ & 0.339 & $\begin{array}{l}0.04 \\
5\end{array}$ & $\begin{array}{l}0.04 \\
5^{*}\end{array}$ \\
\hline
\end{tabular}

*Significant at $P \leq 0.05$.

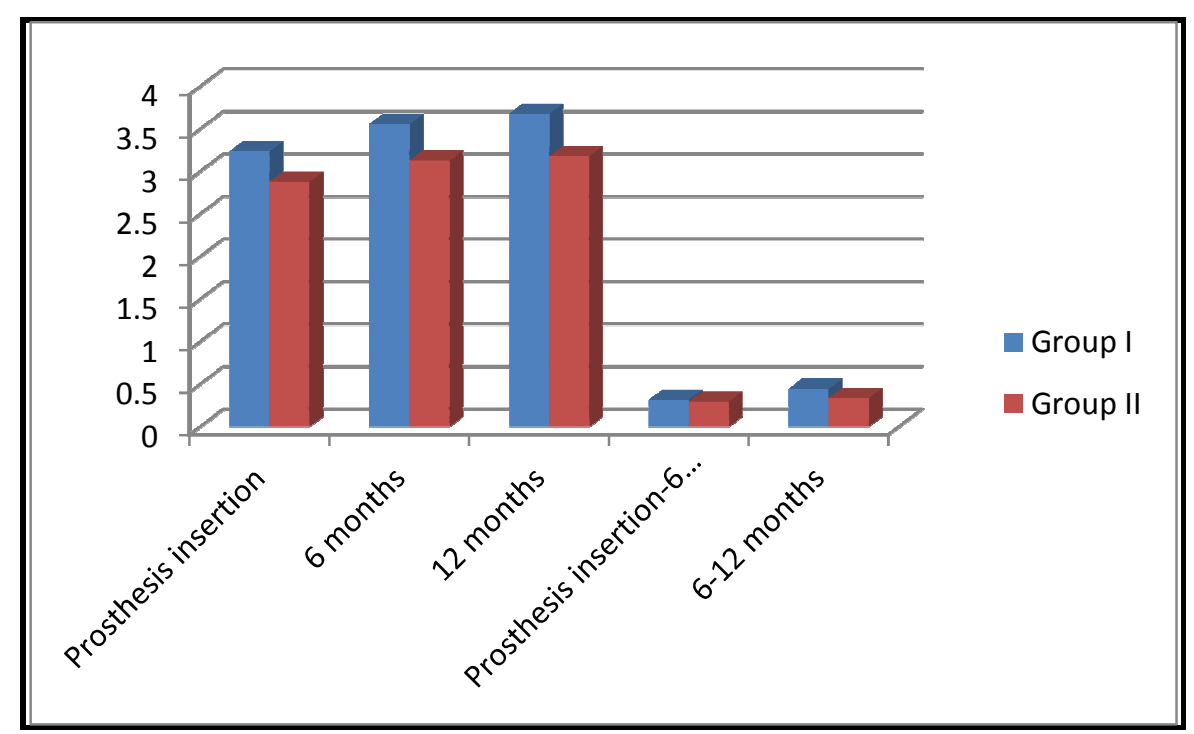

Figure 11: Marginal bone height measurements for the abutments in both groups.

Ashraf E. Eskander, Samira I. Ibrahim and Mushira A. Dahaba (2014), Journal of Research and Practice in Dentistry, DOI: $10.5171 / 2014.948300$ 


\section{b) For the implants}

The mean marginal bone height measurements for group I were 1.59, 1.71 and $1.91 \mathrm{~mm}$ at the time of prosthesis insertion, six and twelve months later respectively. However, for group II, the mean marginal bone height measurements were 1.27, 1.35 and $1.48 \mathrm{~mm}$ respectively. The comparison between the amount of bone height changes in both groups revealed no statistically significant difference $(\mathrm{P}>0.05)$ between the amount of bone loss in both groups after six months. However, after twelve months, patients of group II (the Versacryl clasp group) showed a statistically significant lower mean amount of bone loss $(\mathrm{P} \leq 0.05)$ than those of group I (the metal clasp group) (Table 4, Fig.12).

Table 4: Marginal bone height measurements for the implants in both groups

\begin{tabular}{|c|c|c|c|c|c|c|c|c|c|c|c|}
\hline & \multicolumn{2}{|c|}{ Group I } & \multicolumn{2}{|c|}{ Group II } & \multirow[b]{2}{*}{$\begin{array}{l}\mathrm{P} \\
\text { value }\end{array}$} & \multirow[t]{2}{*}{ Period } & \multicolumn{2}{|c|}{ Group I } & \multicolumn{2}{|c|}{ Group II } & \multirow[b]{2}{*}{$\begin{array}{l}\mathrm{P} \\
\text { value }\end{array}$} \\
\hline Period & Mean & S.D. & Mean & S.D. & & & $\begin{array}{l}\text { Mea } \\
\mathrm{n} \\
\text { diff. }\end{array}$ & S.D. & $\begin{array}{l}\text { Mean } \\
\text { diff. }\end{array}$ & S.D. & \\
\hline $\begin{array}{l}\text { Prosthesi } \\
\mathrm{s} \\
\text { insertion }\end{array}$ & 1.59 & 0.64 & 1.27 & 0.23 & 0.412 & $\begin{array}{l}\text { Prosthesi } \\
\text { S } \\
\text { insertion } \\
-6 \\
\text { months }\end{array}$ & $\begin{array}{l}0.12 \\
7\end{array}$ & $\begin{array}{l}0.02 \\
8\end{array}$ & 0.085 & $\begin{array}{l}0.01 \\
2\end{array}$ & $\begin{array}{l}0.16 \\
9\end{array}$ \\
\hline 6 months & 1.71 & 0.64 & 1.35 & 0.47 & & & & & & & \\
\hline $\begin{array}{l}12 \\
\text { months }\end{array}$ & 1.91 & 0.60 & 1.48 & 0.92 & 0.550 & $\begin{array}{l}6 \\
\text { months- } \\
12 \\
\text { months }\end{array}$ & $\begin{array}{l}0.31 \\
8\end{array}$ & $\begin{array}{l}0.06 \\
8\end{array}$ & 0.212 & $\begin{array}{l}0.03 \\
0\end{array}$ & $\begin{array}{l}0.03 \\
8^{*}\end{array}$ \\
\hline
\end{tabular}

*Significant at $P \leq 0.05$.

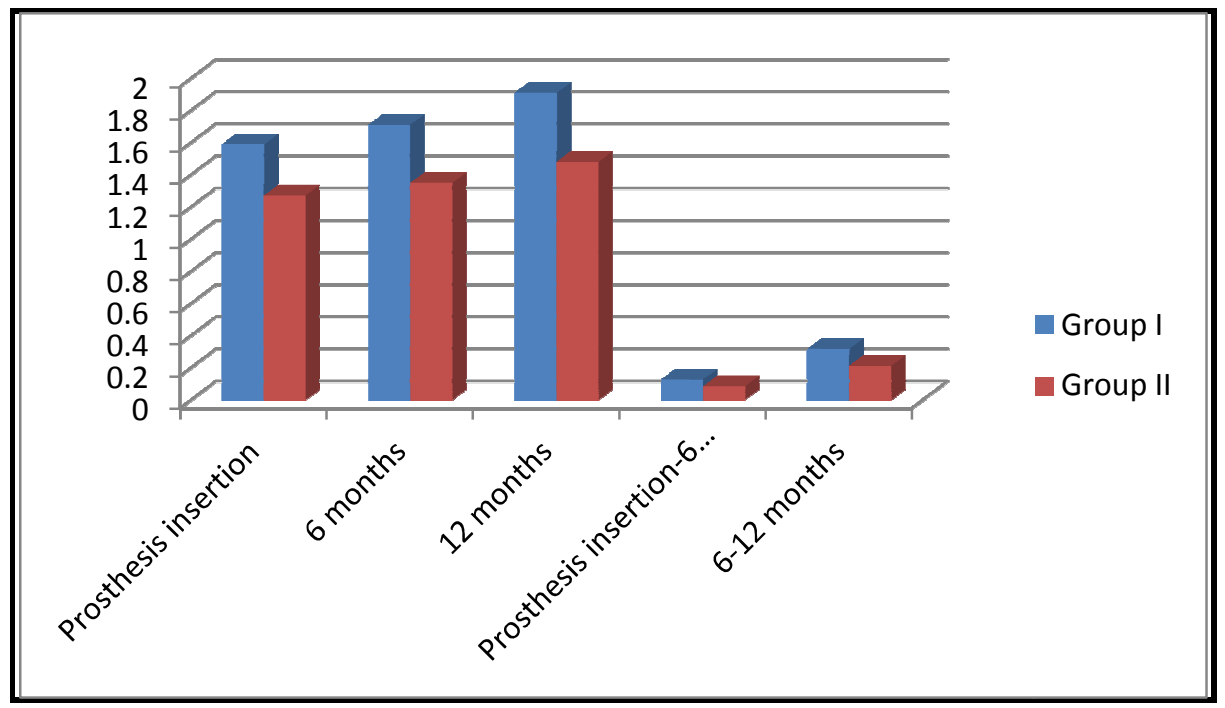

Figure 12: Marginal bone height measurements for the implants in both groups.

Ashraf E. Eskander, Samira I. Ibrahim and Mushira A. Dahaba (2014), Journal of Research and Practice in Dentistry, DOI: $10.5171 / 2014.948300$ 
2) Bone density measurements in both groups

\section{a) For the abutments}

The mean values of the bone density measurements for the abutments in group I were $107.1,110.9$ and 116.7 at the time of prosthesis insertion, six and twelve months later respectively. However, for group II, the mean bone density measurements were $120.1,126.4$ and 138.8 respectively. The comparison between the amount of bone density changes in both groups revealed no statistically significant difference $(\mathrm{P}>0.05)$ between the mean bone density measurements in both groups after six months. However, after twelve months, patients of group II (the Versacryl clasp group) showed a statistically significant increase in the mean bone density measurements $(\mathrm{P} \leq 0.05)$ compared to those of group I ( the metal clasp group) (Table 5, Fig.13).

The percentage change was calculated as follows:

Density (after) - Density (base line) $\times 100$ Density (base line)

Table 5: Bone density measurements for the abutments in both groups

\begin{tabular}{|c|c|c|c|c|c|c|c|c|c|c|c|}
\hline & \multicolumn{2}{|c|}{ Group I } & \multicolumn{2}{|c|}{ Group II } & & \multirow[t]{2}{*}{ Period } & \multicolumn{2}{|c|}{ Group I } & \multicolumn{2}{|c|}{ Group II } & \\
\hline Period & $\begin{array}{l}\text { Mea } \\
\mathrm{n}\end{array}$ & S.D. & $\begin{array}{l}\text { Mea } \\
\mathrm{n}\end{array}$ & S.D & $\begin{array}{l}\mathrm{P} \\
\text { value }\end{array}$ & & $\begin{array}{l}\% \\
\text { chang } \\
\text { e }\end{array}$ & S.D. & $\begin{array}{l}\text { \% } \\
\text { chang } \\
\text { e }\end{array}$ & S.D. & $\begin{array}{l}\mathrm{P} \\
\text { value }\end{array}$ \\
\hline $\begin{array}{l}\text { Prosthesis } \\
\text { insertion }\end{array}$ & $\begin{array}{l}107 . \\
1\end{array}$ & 20.8 & $\begin{array}{l}120 . \\
1\end{array}$ & $\begin{array}{l}19 . \\
2\end{array}$ & & $\begin{array}{l}\text { Prosthe } \\
\text { sis } \\
\text { insertio } \\
\text { n-6 } \\
\text { months }\end{array}$ & 3.22 & 1.24 & 2.14 & 0.74 & 0.086 \\
\hline 6 months & $\begin{array}{l}110 . \\
9\end{array}$ & 25.4 & $\begin{array}{l}126 . \\
4\end{array}$ & 17 & 0.313 & & & & & & \\
\hline 12 months & $\begin{array}{l}116 . \\
7\end{array}$ & 11.4 & $\begin{array}{l}138 . \\
8\end{array}$ & $\begin{array}{l}12 . \\
4\end{array}$ & $\begin{array}{l}0.035 \\
*\end{array}$ & $\begin{array}{l}6 \\
\text { months- } \\
12 \\
\text { months }\end{array}$ & 6.81 & 2.34 & 8.95 & 2.31 & $\begin{array}{l}0.038 \\
*\end{array}$ \\
\hline
\end{tabular}

* Significant at $P \leq 0.05$. 


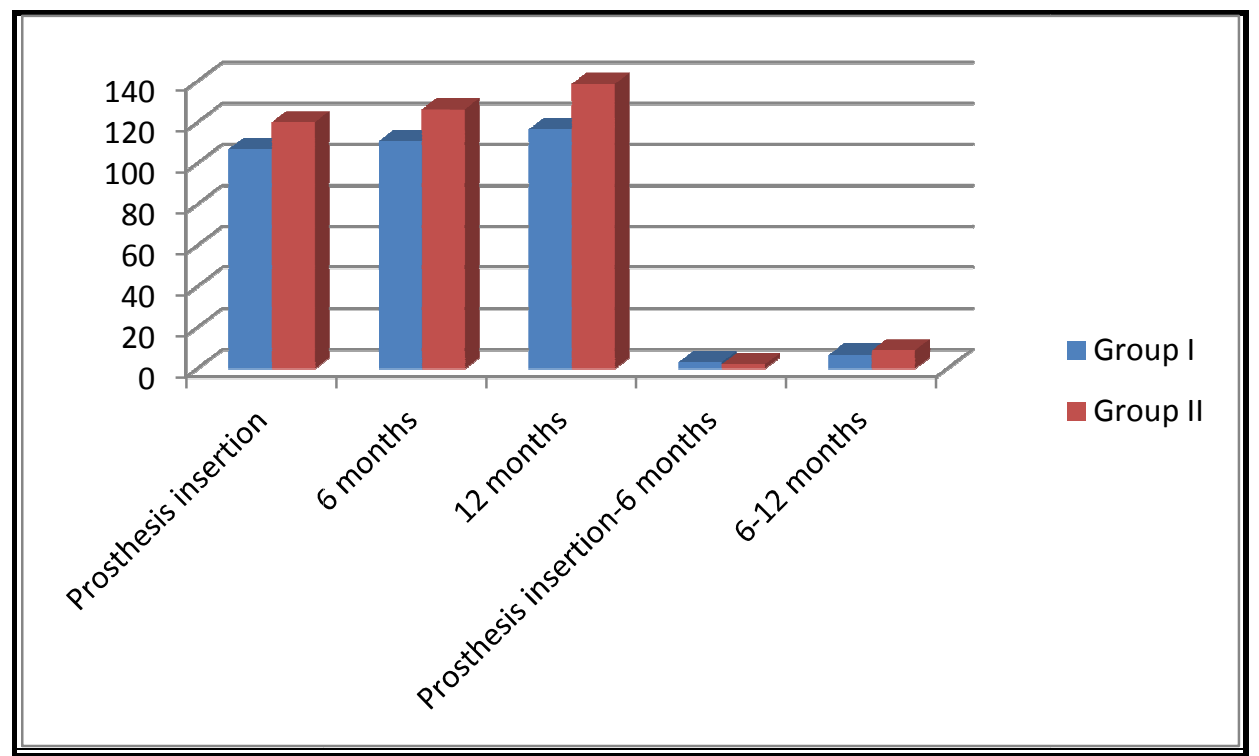

Figure 13: Bone density measurements for the abutments in both groups.

\section{c) For the implants}

The mean values of the bone density measurements for group I were 125.6, 137.5 and 145 at the time of prosthesis insertion, six and twelve months later respectively. However, for group II, the mean bone density measurements were 157.9, 164.8 and 176.7 respectively. The comparison between the amount of bone density changes in both groups revealed no statistically significant difference $(P>0.05)$ between the mean bone density measurements in both groups after six months. However, after twelve months, patients of group II (the Versacryl clasp group) showed a statistically significant increase in the mean bone density measurements $(\mathrm{P} \leq 0.05)$ compared to those of group I ( the metal clasp group) (Table 6, Fig.14).

Table 6: Bone density measurements for the implants in both groups

\begin{tabular}{|c|c|c|c|c|c|c|c|c|c|c|c|}
\hline & \multicolumn{2}{|c|}{ Group I } & \multicolumn{2}{|c|}{ Group II } & \multirow[b]{2}{*}{$\begin{array}{l}\mathrm{P} \\
\text { value }\end{array}$} & \multirow[t]{2}{*}{ Period } & \multicolumn{2}{|l|}{ Group I } & \multicolumn{2}{|c|}{ Group II } & \multirow[b]{2}{*}{$\begin{array}{l}P \\
\text { value }\end{array}$} \\
\hline Period & $\begin{array}{l}\text { Mea } \\
n\end{array}$ & S.D. & $\begin{array}{l}\text { Mea } \\
n\end{array}$ & S.D. & & & $\begin{array}{l}\% \\
\text { change }\end{array}$ & S.D. & $\begin{array}{l}\% \\
\text { chang } \\
\mathrm{e}\end{array}$ & S.D. & \\
\hline $\begin{array}{l}\text { Prosthesis } \\
\text { insertion }\end{array}$ & $\begin{array}{l}125 . \\
6\end{array}$ & 23.2 & $\begin{array}{l}157 . \\
9\end{array}$ & $\begin{array}{l}13 . \\
2\end{array}$ & 0.258 & $\begin{array}{l}\text { Prosthes } \\
\text { is } \\
\text { insertion } \\
-6 \\
\text { months }\end{array}$ & 9.5 & 7.6 & 5.4 & 8.8 & 0.757 \\
\hline 6 months & $\begin{array}{l}137 . \\
5\end{array}$ & 26.9 & $\begin{array}{l}164 . \\
8\end{array}$ & $\begin{array}{l}13 . \\
1\end{array}$ & & & & & & & \\
\hline 12 months & 145 & 22.9 & $\begin{array}{l}176 . \\
7\end{array}$ & $\begin{array}{l}21 . \\
8\end{array}$ & 0.888 & $\begin{array}{l}6 \\
\text { months- } \\
12 \\
\text { months }\end{array}$ & 3.2 & 3.2 & 0.8 & 3.5 & $0.05^{*}$ \\
\hline
\end{tabular}

* Significant at $P \leq 0.05$.

Ashraf E. Eskander, Samira I. Ibrahim and Mushira A. Dahaba (2014), Journal of Research and Practice in Dentistry, DOI: 10.5171/2014.948300 


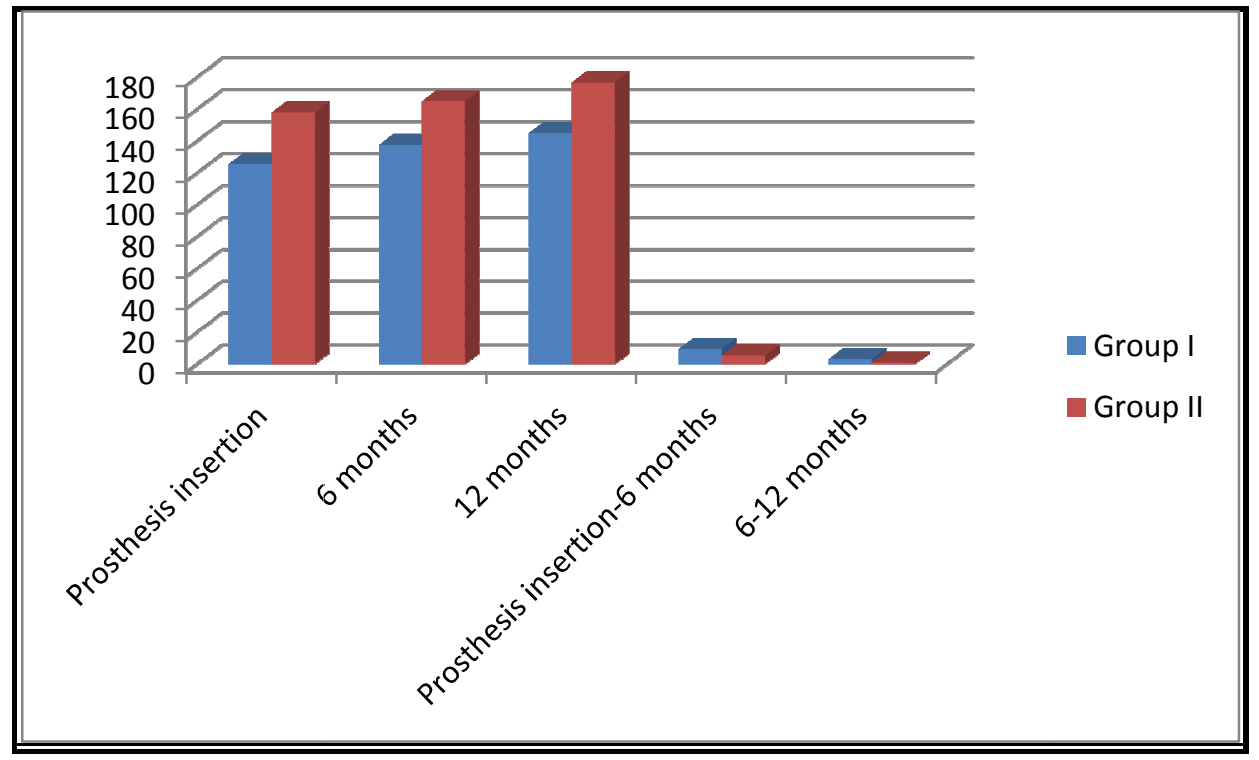

Figure 14: Bone density measurements for the implants in both groups.

\section{Discussion}

Distal extension partial dentures are subjected to a great stresses compared to Class III cases because their support is a combination of tooth and soft tissues, and are subjected to rotations. Therefore, during the formulation of a design for a distal extension partial denture, all the possible movements that may take place must be kept in mind, and all the components of the denture may then be positioned to counteract or prevent as much of the rotation as possible. Therefore, when the treatment is being planned, every effort should be made to retain a posterior abutment tooth to avoid a Class I or Class II situation. Preserving a posterior tooth to serve as a vertical support or even as a partial over-denture abutment is rendering the patient an outstanding service as was reported by Phoenix et al (2008).

It has to be noted that the placement of an implant in the posterior region in distal extension cases, to support a removable partial over-denture because of financial or anatomic limitations may be more suitable in such cases, instead of making a tooth implant supported fixed restoration or even the placement of another implant and construction of a totally implant-supported fixed restoration. This could be attributed to the fact that implant placement in distal extension cases provides a positive distal support that minimizes load transmission to the edentulous ridge reducing its resorption, as well as providing a stable partial overdenture improving its efficiency. Besides, the placement of a ball implant abutment with its retentive clip simplifies the design of the partial over-denture as it eliminates the need for an indirect retainer.

The visibility of the retentive arm sometimes causes a cosmetic problem for patients. Although, an attachment may be considered for these patients, the need for a crown prosthesis, possible endodontic treatment, additional chair-time and post insertion care may make such an option financially unacceptable as indicated by Phoenix et al (2008). 
A nylon removable partial denture (Valplast) provides improved esthetics as it has no metal framework or occlusal rest. However, nylon removable partial dentures are contraindicated in Class II cases, as they lack the basic elements of traditional removable partial dentures such as rigid connectors and occlusal rests. Another negative aspect of using the polyamide base resin is its surface roughness, and difficulty in polishing leading to bacterial and fungal colonization on its surface as was reported by Ito (2013).

On the other hand, technopolymer materials, like thermoelastic resins (Versacryl) have viscoelastic properties. They are prepared to have superior flexibility, which is about ten times as flexible as the metal clasps, and they return to their preset dimensions after being stretched. Therefore, the use of esthetic clasps in removable partial dentures can bring a metal-free smile to the patient as was recommended by Yu and Huang (2012).

Thermoelastic resins can be mixed in different softener/hardener monomer ratios to have different viscoelastic properties according to its application as indicated by Moussa et al (2012).

Therefore, the novality of this research is that it combines the rigidity of chrome-cobalt skeleton partial denture framework with its good support and better load distribution, together with the superior esthetic quality of the thermoelastic (Versacryl) retentive arm. Another important advantage of the thermoelastic retentive arm is that it has an internal memory to return to its original position as compared to the cast clasp, which usually becomes fatigued after about 500 times of insertion and removal, as reported by Tokue et al (2013).

The present study revealed superior results regarding the amount of bone loss, density and gingival condition around the terminal abutment, and implant with the use of the thermoelastic resin (Versacryl) clasp. Besides, this type of clasp arm can be easily adjusted by just putting it in warm water which gives confidence and comfort to the patient, unlike the metal clasp arm. Another important advantage of the Versacryl clasp is that, if broken, it can be easily replaced, as it chemically bonds to the old acrylic resin. In addition, thermoelastic resin clasps are also very hygienic and do not easily stain as they are non-porous and easily cleaned preventing the adherence of debris to the clasp.

\section{Conclusions}

From the results of the present study, it can be concluded that:

1) The use of the thermoelastic (Versacryl) clasp, with its superior properties, is better accepted by the patients, regarding esthetics, retention and efficiency.

2) Both the implants and the abutment teeth reacted more favorably with the use of Versacryl clasps

\author{
Notes \\ ${ }^{1}$ Dentium implants, Seoul, Korea. \\ ${ }^{2}$ Keystone Industries, USA. \\ ${ }^{3}$ Dentium implants, Seoul, Korea \\ ${ }^{4}$ Integration Diagnostics AB, Götenborg, \\ Sweden \\ ${ }^{5}$ Digora Computerized System, Helsinki, \\ Finland. \\ ${ }^{6}$ Rinn manufactures Co. Ligin, III, USA. \\ ${ }^{7}$ Xgenus Degotzen machine, Italy.
}

\section{References}

1) Behr M, Zeman F, Passauer T, Koller M, Hahnel S, Buergers R, Lang R, Handel G and Kolbeck C (2012) "Clinical performance of cast clasp-retained removable partial dentures: a retrospective study," International Journal of Prosthodontics, 25(2):138-144.

2) Budtz-Jørgensen E, Bochet G, Grundman $M$ and Borgis S (2000) "Aesthetic considerations for the treatment of partially 
edentulous patients with removable dentures," Practical Periodontics and Aesthetic Dentistry, 12(8):765-772.

3) Chikunov I, Doan P and Vahidi F (2008) "Implant-retained partial overdenture with resilient attachments," Journal of Prosthodontics, 17(2):141-148.

4) de Freitas RF, de Carvalho Dias K, da Fonte Porto Carreiro A, Barbosa GA and Ferreira MA (2012) "Mandibular implantsupported removable partial denture with distal extension: a systematic review," Journal of Oral Rehabilitation, 39(10):791798.

5) El Mekawy NH, El-Negoly SA, Grawish Mel-A and El-Hawary YM (2012) "Intracoronal mandibular Kennedy Class I implant-tooth supported removable partial overdenture: a 2-year multicenter prospective study," International Journal of Oral and Maxillofacial Implants, 27(3): 677683.

6) Elsyad MA and Habib AA (2011) "Implant-supported versus implant-retained distal extension mandibular partial overdentures and residual ridge resorption: a 5-year retrospective radiographic study in men," International Journal of Prosthodontics, 24(4):306-313.

7) Hamanaka I, Takahashi Y and Shimizu H (2011) "Mechanical properties of injectionmolded thermoplastic denture base resins," Acta Odontologica Scandinavica. 69:75-79.

8) Ito M (2013) "The combination of a nylon and traditional partial removable dental prosthesis for improved esthetics: A clinical report," Journal of Prosthetic Dentistry, 109(1): 5-8.

9) Jivraj S and Chee W (2006) "Treatment planning of implants in posterior quadrants," British Dental Journal, 201(1):13-23.

10) Kaplan P (2012) "Flexible partial denture variations. The use of circumferential, combination, and continuous clasp designs," Dentistry Today, 31(10):138141.

11) Kaufmann R, Friedli $M$, Hug $S$ and Mericske-Stern R (2009) "Removable dentures with implant support in strategic positions followed for up to 8 years," International Journal of Prosthodontics, 22(3):233-241.

12) Kunwarjeet Singh, Himanshu Aeran, Narender Kumar and Nidhi Gupta (2013) “ Flexible Thermoplastic Denture Base Materials for Aesthetical Removable Partial Denture Framework," Journal of Clinical Diagnostic Research, 7(10): 2372-2373.

13) Loe H and Silness J (1963) "Periodontal disease in pregnancy. Prevalence and severity," Acta Odontologica Scandinavica, 21:533-551.

14) Minoretti $R$, Triaca $A$ and Saulacic $N$ (2009) "The use of extraoral implants for distal-extension removable dentures: a clinical evaluation up to 8 years," International Journal of Oral and Maxillofacial Implants, 24(6):1129-1137.

15) Moussa A, Ramadan A, Zaki I, Yehia D, Zeid A and Wael A (2012) "Viscoelastic properties of Thermo-Elastic resin reline with different ratios," Journal of Applied Sciences Research,8(3):1477-1483.

16) Ohkubo C, Kobayashi M, Suzuki $Y$ and Hosoi T (2008) "Effect of implant support on distal-extension removable partial dentures: in vivo assessment," International Journal of Oral and Maxillofacial Implants, 23(6):10951101.

17) Osada H, Shimpo $H$, Hayakawa $T$ and Ohkubo C (2013) "Influence of thickness and undercut of thermoplastic resin clasps on retentive force," Dental Materials Journal, 32(3):381-389.

18) Phoenix RD, Cagna DR and DeFreest CF (2008) Stewart's clinical removable partial 
prosthodontics, $4^{\text {th }}$ edition, Quintessence publishing Co. Inc., Chicago, USA.

19) Singh $K$, Aeran $H$, Kumar $N$ and Gupta N (2013) "Flexible Thermoplastic Denture Base Materials for Aesthetical Removable Partial Denture Framework," Journal of Clinical Diagnostic Research, 7(10): 23722373.

20) Sykes LM, Dullabh HD, Chandler HD, Bunn B and Essop AR (2002) "Flexibility of technopolymer clasps compared with cobaltchromium and titanium clasps," Journal of the South African Dental Association, 57(5):166171.
21) Tokue $A$, Hayakawa $T$ and Ohkubo $C$ (2013) "Fatigue resistance and retentive force of cast clasps treated by shot peening," Journal of Prosthodontic Research, 57 (3):186-194.

22) Turkyilmaz I (2009) "Use of distal implants to support and increase retention of a removable partial denture: a case report," Journal of the Canadian Dental Association, 75(9):655-658.

23) Yu H and Huang W (2012) "Category design and clinical application of esthetic clasps," Hua Xi Kou Qiang Yi Xue Za Zhi, 30(5):447-452. 